\title{
山形影，日向川流域の新生代火山岩についで
}

\section{On the Cenozioic volcanic rocks around Nikko \\ River, Yamagata Prefecture}

\author{
今 田正 (Tadashi Konda)*
}

\begin{abstract}
The Nikko River district was hitherto surveyed by many geologists stratigraphically. The writer made some petrological observations and laboratory works during $1951 \sim 1953$, in order to clear the Cenozoic volcanism in view of orogen theory.

The district consists of the following eight formations in ascending order; that is, the Wadaki, Aozawa, Yaegawa, Kitamata, Minami, Rokusuke, Jozenji, and Quaternary formations. These formations range from the miocene to the quaternary in age, and various volcanics are included in these formations. By his geological and petrological studies, the writer obtained the following volcanic phases and geological conditions.
\end{abstract}

\section{A Volcanic phase}

1st stage. Agglomerate or eruption and green tuff explosion (basalt or spilitic basalt)

2nd stage. Sheet or phacolith intrusion (dolerite)

3rd stage. Dyke or stock iutrusion (plagio-liparite and partly dacite)

4th stage. Lava or agglomerate eruption (basic andesite)

5th stage. Young volcanism (Chôkai volcanics)

B Geological condition

Ist stage. Sedimentation of muddy phase

2nd stage. (sinking of basin) Sedimentation of muddy phae followed by sandy mudstone (later stage of sinking)

3rd stage. Initial epilogenic movement with brecciated faulting

4th stage. Marginal condition of uplift

5th stage. Faulting which occured at marginal zone of the Dewa hill range.

Next the petrological characters of volcanics of the districts are indicated as followes; Andesitic rock is rare or absent. All volcanics of miocene age have no hypersthene and often include basic bytownite. Chemically they show high contents of $\mathrm{Al}_{2} \mathrm{O}_{3}, \mathrm{CaO}$ and specially $\mathrm{H}_{2} \mathrm{O}$ in basalt. And a part of basalt is spilitic.

山形大学交理庵部

1) 今田 正；日向川流域の新生代火山岩，昭28年6月，日本地質学会東北支部例会講演 今田 正; 日向川流域の新生代火山岩の岩石学的特街, 昭28年10月，日本地筫学会 東北支部例会丵惩 


\section{1 緒夆}

当地域は従来東北裏日本油田地域として古くは村山賢一氏 ${ }^{11}$ ；最近では 加藤磐雄 ${ }^{2}$ ，田ロ一雄 ${ }^{31}$ ，阿部正宏つ諸氏及び帝石関係 ${ }^{4}$ の諸氏に依り調 查が行われた。

然し之等の調查は油田地質を主とし：層位学的観察が主に行われて来た。 筆者は昭和 26 年以降，野外調查を行つて来たが，本調査は火山岩の産状及 び岩石学的性質を検討し，更に堆積相攻び構造よりの地質環境を解析し， 両者の関係を追跡するのが主であつた。その結果, 所謂新生代地向斜とし でその中に繰込まれた火山岩の岩石学的性質と地質環境の間に関聯性の ある事が判つた。然も両者の相互関聯度特に現象の経過と云う面で注，地 向䣄火成活動としての系統性に多くの類似点が認められる。此処にその内 容を発表し大方の御検討を乞う次第である。

尚此の研究は，東北日本新生代火山岩研究の一雗として行い，小倉死教 授，及び北大、石川俊夫教授の御指導を戴いた。明記して深謝河る次第で ある。

\section{2 地質}

日向川流域は，出羽丘陵の一部を占め飽海油田の北部に位置し，所謂鳥 海油田とも呼ばれ，東北赛日本の゙油田地域の一員をなしている。筆者の調 查に依ると当地域の地質には次に示す殿序が認められる。即ち有部より，

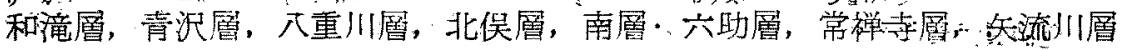

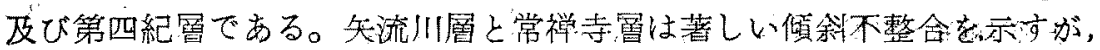

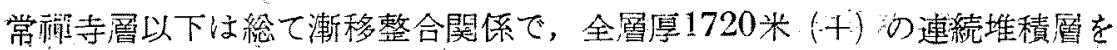
示す。

一般に下部層は火山性确㞕岩及び火山岩を件い出羽丘陵の中核部に露出 し，上部層は出羽丘陵と庄内盆地耼野部との間に低い丘陵地を形成してい る。・各留は略南北の方向性を示し，常就寺層より和滝層まで。著しい褶曲 構造を示している。断層系も比較的多く，大断層は上部層（常籍寺層）を 切つている。次に各層の記㸌を示す。

A) 和境層 標式地は荒瀨川上流，和潼附近にみられる。緑色凝瓜岩老殆んど介在 せず，灰色泥岩層に硬質頁岩を展及介在する。現在では化石は痤出しはい。

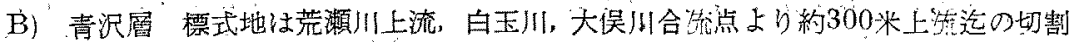

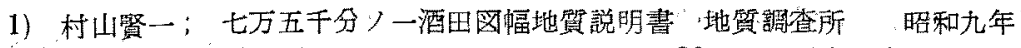

2,3) 加藤磐堆；東北のグリンタフに就いて，昭和28年地質学会焧会パンフレット

4) 細井弘, 樹下惺; 庄内平野周辺のグリンタフ,昭和28年地質学会総会パシフレット 


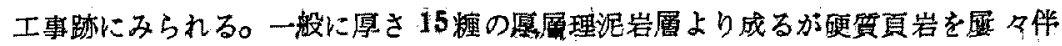

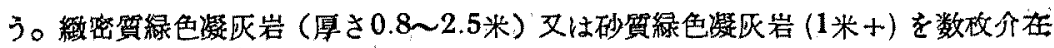

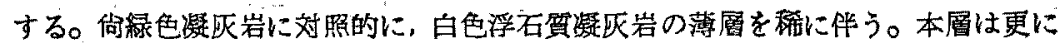
粗粒玄武岩乃至去武岩の岩床，又は集塊岩が発達し更に斜長流綮岩及び石英安山岩 の岩脈，岩株の䐝入を受けている。荒瀬川，当玉川活域には，灰色汁岩中に，魚類

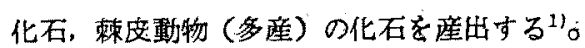

C) 八重川層 日尚川支流、八重川流域に標式的にみられる。履位的に青沢層の上位

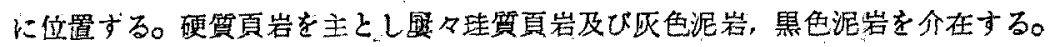
・各々，厚さ $5 \sim 10$ 栍の層理を示し，膺々硬質頁岩の縞状互層と厚さ 1 米士の网 色泥岩と累層状態を示す。

本層中には，砂質浮石复白色凝灰岩（0.5１.3米）を介在するが，緑色凝欧岩類 は全く諗められない。

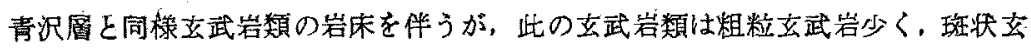
武岩を主とする点に於いて明瞭な相遧が䜅められる。化石にこしいが，下青沢部落 対岸の峷に，二枚貝化石を産する。

D) 北俣層 標式地は北俣村庇島一梅ヶ沢一相沢神社の道路筋に露出する。八重川 層との関係 ${ }^{21}$ は断層 (带)で接している。本層は暗反色泥岩をとし，比較的層理

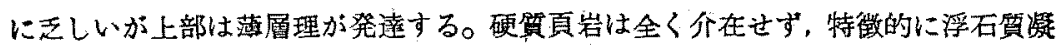
死岩乃至同繁砂岩 $(0.6 \sim 2.3$ 米) を数枚介在する。

E)，南層 下青沢南部落より中台に至る河底に発達する殆んど 無尿理暗欧色矽質泥 岩層である。本層は北俣層と六助層の中間に岩相上，特徽的に捉えられるものです る。現在では化石は発見されない。

F) 六助㬝 本層は青沢村六助部落対捈の崖に標式的に露出する。下部は無層理暗以

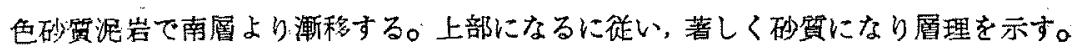
上部は細粒〜中粘暗青色砂岩（部分的砂賀）を介在し，貝化石を伴う。上部砂岩

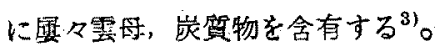

G) 常禅寺層 本層は常禅寺対岸の崖に標式的露出を示す。未凝固租粒砂又は細磁 を主とする。上部は一般に市 2〜5 橡の暗青色粘土と，粗粒㫾(1.5米土)の互層 を示す。下部に従い，凝結度を增し，巾2 3 米の中粒及じ数粒㫾岩互層状熊を示

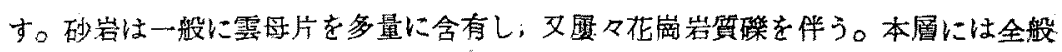
的に炭翼物を著しく含有し，最下部には厚さ $2 \sim 4$ 粧の西炭層4〉を2 3枚介在する。

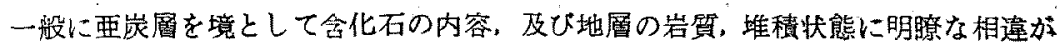

1) 倚次 $\emptyset$ 化石を得た。 Flavamussium tairanium

2）調盉地域北俣部落南方約‡籸の做部落地带では下部八重川層と漸移整合する。

3) 本藑には次の様な化石を多量含む。

Japelion adelphicus Dall, Ethalia sp., Macoma tokyoensis Makiyama; Tectonatica janthostoma, Fulgoraria cfr. megaspira. Turritella saishuensis Yokoyama, Babylonia japonica. Reeve, Clanus sp.

4)出羽丘凌東縁及び新庄盆地に良好な発迹を示高崖層群に㸚比されるが，詳細は 検討中である。何本層には石英安山岩質浮石貿㠜在岩を塊状に含む場合が稀にあ そ。然し新庄盆地の重炭層には石英安山岩質㠜灰岩を豊富に介在する。 


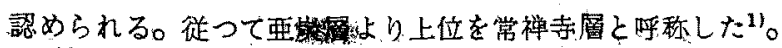

H) - 矢流川層 本層は矢流川及ひ常禅寺部落対岸公園地带に標式的に観られる。主 に出羽丘陵西縁低丘陵地の縁辺に沿い，即ち庄内平野の周辺に限られて分布する。

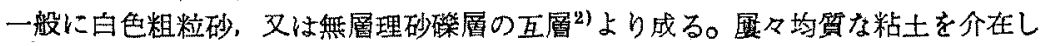
粘土は部分的に黒雲母片および植物蒦を含む。向本層は，下部層を不整合に被㪇し 上限は段丘層磂に傾塗不整合で被覆される。

本層には玄武岩嘪安山岩の熔岩又は集塊岩が介在じ，常禅寺公園入口に於いては 石英安山岩䁈凝灭岩を価少介在する。

以上の各層を通覧すると，出羽丘陵中核带，又愔庄内，最上，両油田の 中心部としての日向川流域は, 当初, 和滝, 青沢, 八重川，北俣の各層に みられる様に深海性の堆積相を示し，次に浅海を経て，漸次，六助，常樿 寺にみられる浅海乃至瀕海性の堆積相を示すに至つたものと解される。最 後に矢流川層にみられる様に，前述の各層に不整合に最後の乱堆積相が認 められる。向此等の地層と東北震目本の標準地層との対比を考察すれば和 滝層青沢層は台島層に，八重川啳は女川層に，北俣層は航川層に，南層は 北浦層に，六助層及び常福寺層は脇本層に又矢流川層は鮹川層に各々対比 されるものと考えられる。

\section{3 火山岩の産出狀態}

日向川流域には，玄武岩類，䣄長流效岩之の他玄武岩質安山岩，石英安 山岩等の各種の火山岩, 及び火山性砕㾓岩が発涬する。此等の火山告は油 田地域としての地層に相伴われ複雑な座出状態示している。次に産状を 生成順に述べよう。

（1）集塊岩及び集塊質熔岩 標式的に日向川本流，熊沢川，大芦沢上流に広範に分布 する。大芦沢では，青涩層中に介在し，能沢川では，青沢绝に一部介在し，一部は

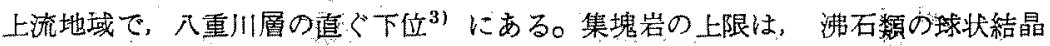

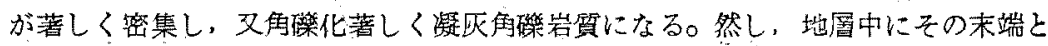
思われるものが，巾 4〜5 米で介在する点より，地層堆積時の噴出によると解される。 又集塊岩の一部は，緻密化し熔岩流に漸移するのが認められる。

此れはスビライト質玄武岩で特に注目される。向青沢層中に厚さ数米の緑色凝灰 岩類が挾在するが此れは集塊岩の火成活勤と相前後するものと解される。

1) 本層も化石を多産し，六助層に含まれる化石之共通のものも多い。次のものが認 められた。 Anadara subcrenata, Acila sp., Buccirum cfr. tenuissium Kuroda, Macoma tokyoensis Makiyama, Neverita cfr. didyma, Patinopecten kurusareaensis, Chlamys swiftis, Yoldia johanni Dall, Truncacila nakazimiai Otsuka, Glyoymeris yessoensis, Neverita cfr. Kiritaniana, Laevicardium angustum, Mercenaria stimpsonii.

2) 走向傾斜を明膫に測定する事は困難であるが，地域的に $6 \sim 10^{\circ}$ の傾斜をもつ。 然し下部層と伴つて褶曲檏造は認められない。

3) 断層で接する可能性がある。向大前川上流の集塊岩は瓜籍々露出するが層準不明。 
（2）进入岩床乃至弧盤 荒瀬川（大俣川，白玉川）上流，日向川本流に標式的に露 出守る。此れは青黑色を呈する玄武岩類で常に地層に平行に入り，所謂" 岩床 "上 して，東北塞日本の新第三紀層の泥岩相に極めて普遍的に認められるものである。 第 1 図

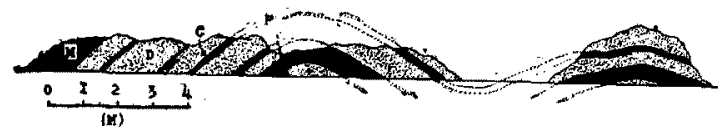

粗粒玄武岩の産出状驡（於前川地点）

$M$ 泥岩 $\mathrm{D}$ 粗粒立武岩 $\mathrm{C}$ 泥岩及び粗粒玄武 岩接触带（第 2 図参照）Ｆ 断層
当地域ては和滰層, 青沢層, 八重川層の各層に伴い産出 する。一般に下部層（和䄋 層) に伴方九る場合，厚さ 100 数米に及び延長 2 䊅の 岩体走し数枚加泌集する。 上部層 (北俣層) に伴うも
第 2 図 接触带 (実測)

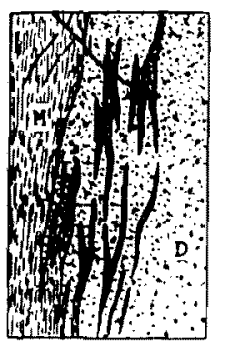

$1 \mathrm{~cm}$

$M$ 泥岩 $\mathrm{D}$ 粗粒立武岩” 黒線は方解石脈。
のは厚さ最大 5 米(十）の小䇹体を示し量的にも少い。 第 1 図は前川に於ける産状を示したものである。薄い 岩体の場合は明に，地層に相平行し，地層と共に㗩曲 を示している。地層との接触部は明確な境界を示すの が普通であるが，展マ複雑なる迸入形態を示す(第2図)。 文末端が岩脈状を示す場合もある。一般に薄い岩 体の場合は細粒䝷であるが，潪次厚さを増大し20米以上 の場合は，粗粒玄武岩になる。台40米以上の厚さを示 す場合その末端部に於いて数林に分䁌し，平行岩床を 示す。岩床の上盤及び下盤は，常に泥岩相で，硬化作用

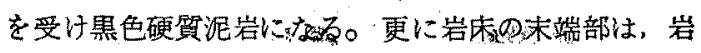
床及已゙硬诉泥岩を貫く方解石脈方著しく発達する。

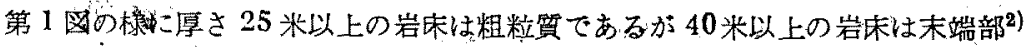
は数枚に分れ平行岩床となり，著しく細粒化する。又細粒臂岩床の場合注，沸石球 状結晶が密に散在するのを特徽とするが粗粒質の岩床には巾 2 種大の緑泥石石英

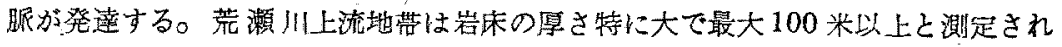
る。特に背斜軸の位置に於いて最も厚い。尚厚大な弧盤を示すが，岩漿分化に依る 酸性岩体及じヘグマテック脈は全く認められない。上の産状を示す玄武岩類は迸 入岩床又は弧盤として, 和滝層, 青沢層, 八重川層堆皘に前後して迸入したものと解 される。

(3) 岩株及び岩脈 出羽丘陵の春梁地带に, 又は替梁の縁边部に略南北方向を示し て，岩脈乃至岩株として露出する斜長流紋岩がある。

答梁地带では一般に岩体は大で岩株の䧹状を示す。縁辺部には狭長で正長した 带状の岩脈を示している。此等の岩格及び岩脈は岩䁈も極めて類以し，一定方向に 排列する点より劧察するに䡒入時期は略同一であると解される。現在迄の調査 ではいづれも急傾䣄の接触面を示し青沢層及び八重川層を切る。更に前川上流に 於いては粗粒立武岩を切り，一部は同岩を捕爑するのが認められる。又前川上流に

1) 粗粒立武岩酒層に平行迸入し泥岩を捕獲する。向捕獲された泥岩の層理は接触 面に略平行している。份本図は貫入上盤の産状である。

2) 中心より分岐するまでは少くとも500米以上の距離は推定出来る。 
おいては，立武岩質集塊岩を切る点より，当地域の基性玄武岩類より後期の貫入に よると解される。此等岩株及び岩服は，比較的均筫な斜曼流紋岩であるが，前川上 流の岩株は南端部に於いて渐次岩筫が変化し，石英安山岩”になる。その他日向川

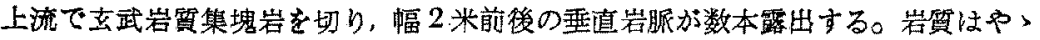
斑状の玄武岩である。

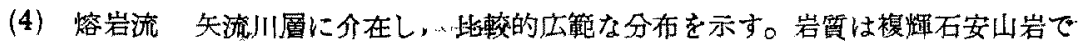

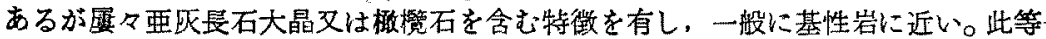

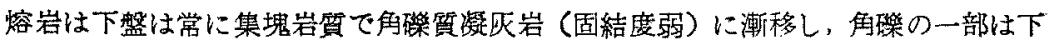
盤の砂岩に含まれ地層堆積時の噴出と明確に癹められる。即ち新第三紀末期の出 羽丘陵の浮き上り的陸化に伴う；縁辺帯に南北力向に鳥海火山基底より，矢流川に 互り噴出したものと解される。最後に第四紀火山としての烏海火山は2゙熔岩流を 伴う矢流川層を被覆し，熔岩溢流と拖出物堆積を行つている。

\section{4 岩 石 記 載}

当地域に産する岩石杜比較的単柧なものである。その中，代表的な岩石 を举げるとスピライト筫玄武岩，粗粒玄武岩，玄武岩，玟状玄武岩，安山

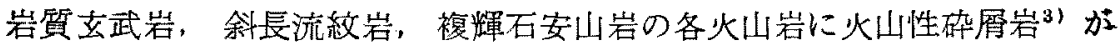
ある。次に各岩死について記誡を試みよう。

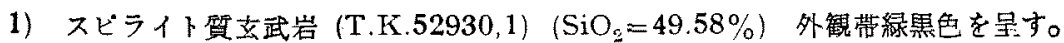
雷々方解石の細脈に貫かれ沸石の球状結晶散在し，“二次的変質漖しい。橉成鉱物は

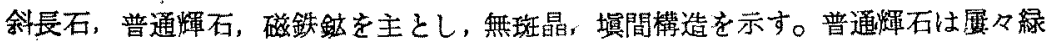
色鉱物に変化する。䣄長石は一般に径 $0.2 \sim 0.5$ 秏長杜状を示し，比較的活染し， $n_{1} \mathrm{D}=1.5410 \sim 1.5430, \mathrm{An}_{27} \sim \mathrm{An}_{30}$ の成分を示す。然るに新鮮な斜長石は最大対 称消光角大て $\mathrm{An}_{100}$ の成分を示す。何化学成分を(第 1 表 5) みるに， $\mathrm{Na}_{2} \mathrm{O}$ 成 分比較的大であり，䣄長石の酸性なることと共に所謂“'spilitic，，の岩質を示す。

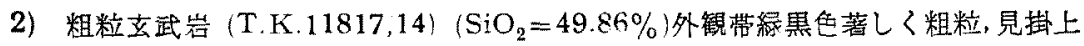
深成岩様を呈す。鏡下では涂長石，普通煇石，磁鉄鉣を主要糐成鉱物とした間粒乃 至オフイテツク糤造を示す。

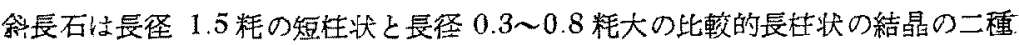

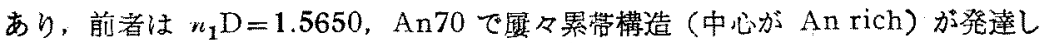
後者は $n_{1} \mathrm{D}=1.5630 \mathrm{An}_{60}$ で多少の成分差が存在する。

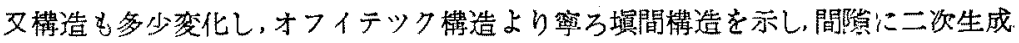

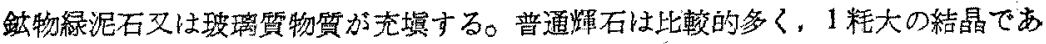
るが，一般に自形性にそしく䣄長石の間償をみたしつ〉結晶が成長した形態をるる

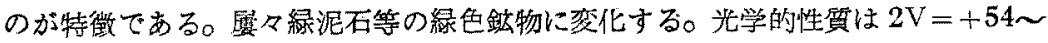

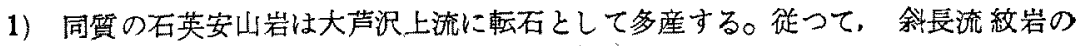
異相としてではなく，単独岩脈としての産出名推定される。

2)鳥海火山岩数は調查中に就き样細な報告は别の機会にし度い。

3) 所語笅兏岩類 


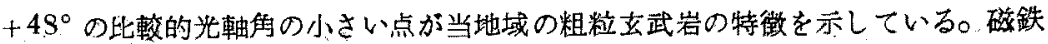

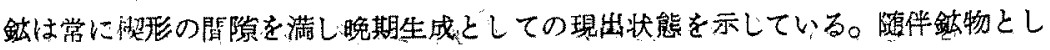
て，当地域の粗粒立武岩に多いのは、燐灰石である。特有の針状結晶を示し，斜長

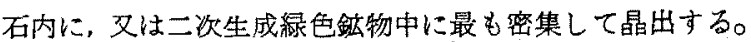

3) 支武岩 (T.K. 53531,7$) \quad\left(\mathrm{SiO}_{2}=47.10 \%\right)$ 外觀带緑青色を呈す。粗粒去武岩の末

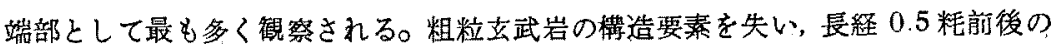

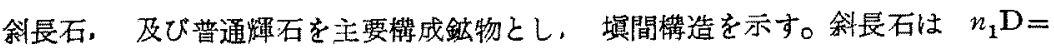
$1.5610, \mathrm{An}_{65}$ の成分を示す。然し玄武岩と粗粒立武岩は玟状構造を漸移带にして移 り変るのが普通である。

4) 斑状去武岩 (T.K.52928，14) $\left(\mathrm{SiO}_{2}=47.50 \%\right)$ 外観带青色径 1.0 1.5 粝大. 斜 長石大晶を含有する粗粒岩で犀々沸石の放射状結晶を散在する。

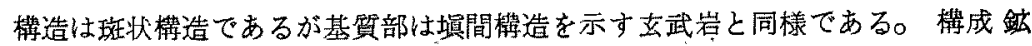

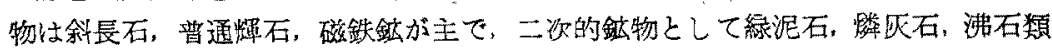
功比較的多く勇め引れる。

斜長石は略三種存在し, 径 1.2 粧. 短杜状結夰は, $n_{1} \mathrm{D}=1.5720 \sim 1.5735, \mathrm{An}_{\mathbf{8 2}} \sim$

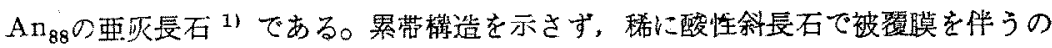
みである。比較的簡単な双晶型を示し，包襄物にそしく稀に普通輝石粒を含む。次 に長胥 3.5 粍大の短柱状結晶は $\mathrm{n}_{1} \mathrm{D}=1.5645 \sim 1.5630, \mathrm{An}_{68} \sim \mathrm{An}_{75}$ の成分を有し 量的に最多い。以上の䣄長石が斑晶の位置に晶出し，斑状構造を示す。

基貿部は長杜状叠 0.4 籷大の斜長石 $\left(\mathrm{An}_{60}\right)^{2)}$ 及び曾通輝石より成る。

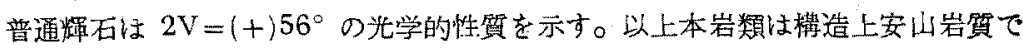
あるが化学成分（第 1 表 1 ）は玄武岩の成分を示す。特に西死支石を含み $\mathrm{Al}_{2} \mathrm{O}_{3}$, $\mathrm{CaO}$ 成分多いものを特徽とする。

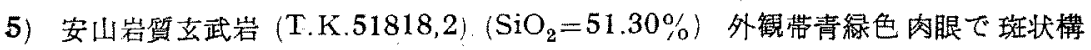
造明臆，鏡下では玟晶の位置に斜長石があり，普通煇石は基質部にのみ晶出する。 斑状長石 $2 \sim 3$ 粍大では $n_{1} \mathrm{D}=1.5660 \sim 1.5635, \mathrm{An}_{68} \sim \mathrm{An}_{72}$ の成分を示し，基質 部斜長石は $0.3 \sim 0.5$ 精，短柇状結晶は $n_{1} \mathrm{D}=1.563 \sim 1.560, \mathrm{An}_{60} \sim \mathrm{An}_{66}$ の成分を 示し,両者の間に著しい成分差は認められない。向基䁚部には普通煇石 $(2 \mathrm{~V}=(+)$

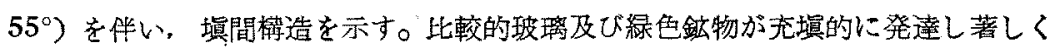
燐西石を伴う。

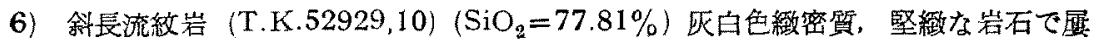
マ淡緑色を呈す。鏡下に於いては明瞭な斑状構造を呈する。

斑晶は量的に著しく少いが䣄長石及び有色鉱物方認められる。斑状涂長石は長 径 3〜5 粍大で活染著しい。新鮮な部分は $n_{1} \mathrm{D}=1.545, \mathrm{An}_{34}$ の andesineである。

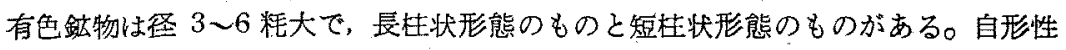

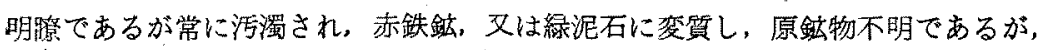

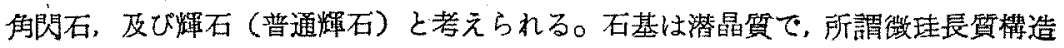

1) 単双晶を示す。且双晶の狭長な部分に接合面に斜めに或方向性をもつ crack が配列状態で入つているのを特徵とする事が石川俊夫教授に依つて指摘された。

2)，最大対称消光角より概測 
を呈するのを特嵝とする。

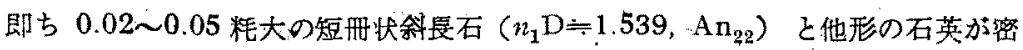

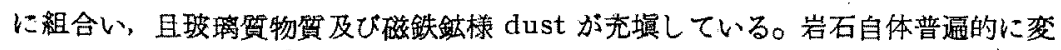
筫し，完全に新鮮な部分はないのが丵通である。一般に緑泥石化及び綟雲母化作用 を受けている。尚，化学成分（第 1 表 4)上 $\mathrm{SiO}_{2}$ 量大であるが斑晶石英を伴わな いのを特徴とする。

7) 石英安山岩 (T.K.5361,10) $\left(\mathrm{SiO}_{2}=66.16 \%\right)$ 外稫滞褐厕色を呈し，著しく粗箖 な感じを与える。鏡下では 10 粍前後の亜灰長石及び角閃石の大晶を含み（最大量

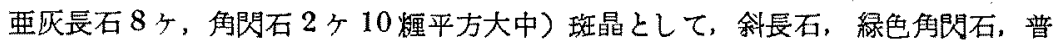
通輝石を含む。石基は 0.2 粍大，斜長石及び玻璃より成り，石英粒を潞々介在する。 部分的に著しく粗面岩構造を旺する。

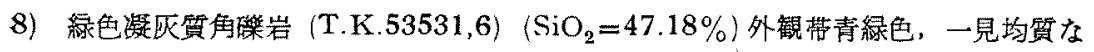
岩質を示すが，立武岩刍砶を含み，泥岩をビッチ状に介在する。層理は殆んど認め られない。鏡下に於いては䣄長石及び殆んど緑泥石化せる蛼石より成る立武岩角

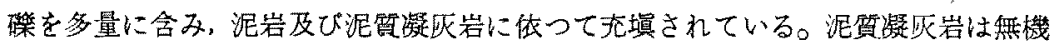

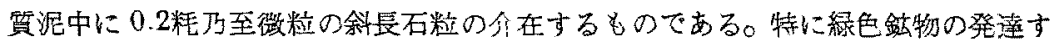

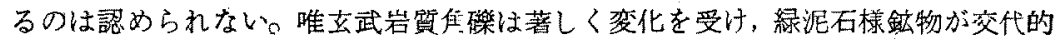
に発迲する。尚本岩類の特徽は，石英粒がない事及び方解石が細脈状に，又は散点 状に含まれ，著しい calcitization。示すのは注目される。

\section{5 崖石學的特徽}

日向川添惐火山岩の特接として重要なのは，新第三紀に中性岩，即ち安 山岩を全く久き，新第三紀末期より第四紀に互り，初的て安山岩の出現す る点である。第 3 図は当地域の火山岩の硅酸量頻度曲線1である。同罒に

第 3 図

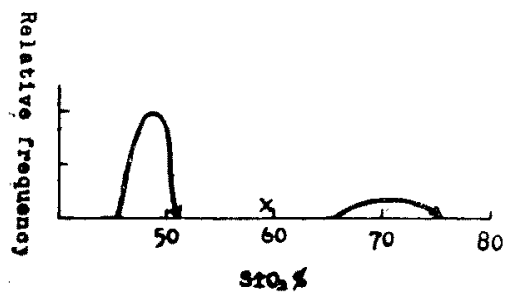

昌向川流域新生代火山岩珪酸量頻度曲線
依ると， $\mathrm{SiO}_{2}$ 成分 $46.64 \%$ より $51.30 \%$ に互る基性岩の火成活動と $66.16 \%$ 上 り $77.81 \%$ に互る酸性岩漿の火成活 動が対照的に行はれ，寧ろ東北日本 に特有の輝石安山岩を全く欠く点は 著しい特崲としなければならない。 劣石英安山岩 $(66.16 \%)$ 注斜長流紋 岩の一異相として産出するに過ぎず， 酸性岩は $70 \%$ 前後のものが量的に大きいとも云い得る。尚化学成分上の

1) 地質図内の各火山岩の露出面積河鳥海基底熔岩 $\left(1.25 \mathrm{~km}^{2}\right)$, 石英安山岩 $\left(0.37 \mathrm{~km}^{2}\right)$ 斜長流紋岩 $\left(7.25 \mathrm{~km}^{2}\right)$ ，集塊岩及び同質熔岩 $\left(8.75 \mathrm{~km}^{2}\right)$, 斑状玄武岩及び安山岩 質玄武岩 $\left(1.25 \mathrm{~km}^{2}\right)$, 粗粒玄武岩 $\left(9.7 \mathrm{~km}^{2}\right)$ と測定される。此れを各少山岩の相対 的量とし，量を概定し各火山岩の $\mathrm{SiO}_{2}$ 成分より相対的頻度を求めた。

図中の×印は鳥海从山岩の位置である。

詳細な調查と分析値少い為正確は期し難い，参考まで。何鳥海火山は調查中。 
特徵として $\mathrm{Al}_{2} \mathrm{O}_{3}$ 及び $\mathrm{CaO}$ 成分が全般的に大であり，玄武岩の一部は $\mathrm{Na}_{2} \mathrm{O}$ 成分多く，スビライト質の性格を持つ。構成鉣物よりみた特徵とし ては，鳥海火山基成の火山岩及び鳥海熔然を除いて全岩に全く紫蘇輝石を 欠く点である。此れに対照的に亜灰長石が基性岩及び酸性岩にも，又中性 岩にも，比較的共通して含まれている点は一つの特徵”と認められる。

第 1 表

Chemical compositions of volcanic rocks from Nikko povince

\begin{tabular}{l|r|r|r|r|r}
\hline & 1 & \multicolumn{1}{|c|}{2} & 3 & \multicolumn{1}{c|}{4} & \multicolumn{1}{c|}{5} \\
\hline $\mathrm{SiO}_{22}$ & 47.50 & 49.86 & 48.06 & 77.81 & 49.58 \\
$\mathrm{TiO}_{2}$ & 1.00 & 1.23 & 0.97 & 1.06 & 1.50 \\
$\mathrm{Al}_{2} \mathrm{O}_{3}$ & 21.92 & 18.37 & 18.44 & 9.80 & 15.12 \\
$\mathrm{Fe}_{2} \mathrm{O}_{3}$ & 5.46 & 3.61 & 4.56 & 1.53 & 4.08 \\
$\mathrm{FeO}$ & 4.37 & 5.94 & 4.64 & 0.43 & 5.20 \\
$\mathrm{MnO}$ & 0.08 & 0.08 & 0.06 & 0.05 & 0.08 \\
$\mathrm{MgO}$ & 3.20 & 5.59 & 8.01 & 0.75 & 7.02 \\
$\mathrm{CaO}$ & 9.53 & 8.88 & 8.21 & 1.00 & 5.89 \\
$\mathrm{Na}_{2} \mathrm{O}$ & 3.48 & 2.54 & 2.13 & 4.35 & 3.81 \\
$\mathrm{~K}_{2} \mathrm{O}$ & 0.57 & 0.60 & 0.71 & 2.26 & 0.42 \\
$\mathrm{H}_{2} \mathrm{O}+$ & 2.73 & 2.81 & 3.69 & 0.82 & 4.13 \\
$\mathrm{H}_{2} \mathrm{O}-$ & 1.00 & 1.96 & 3.28 & 0.35 & 2.15 \\
$\mathrm{P}_{2} \mathrm{O}_{5}$ & 0.08 & 0.09 & 0.03 & 0.13 & 0.10 \\
$\mathrm{Total}$ & 99.89 & 99.42 & 99.40 & 99.67 & 96.65 \\
\hline
\end{tabular}

1. Porphyritic basalt (T. K. 52928, 14)

2. Dolerite (T. K. 51817,14)

3. Andesitic basalt (T.K.51817,7)

4. Plagio-liparite (T.K. 52929, 10)

5. Spilitic basalt (T.K.52930,1)

\section{6 火山岩史}

火成活動は地質環境と密接な関聯を示す様である。日向川流域は所謂新 生代の地向斜として観祭され全層愿略 2000 米に及ぶ。地層堆積より現在 の位置まで, 種々の発展の跡が窥筧われる。筆者は火山岩と地質環境の相互 関係を求める為，火山岩史の追跡を行つた。其の䋨果は第 2 表である。 此の表を基準にし，火山岩史の各々の説明を行う。

1) 含平灰長石岩に就いては，田ロ一雄氏が既に報告されている。

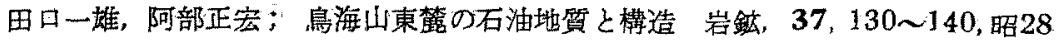


第 2 表火成活動史

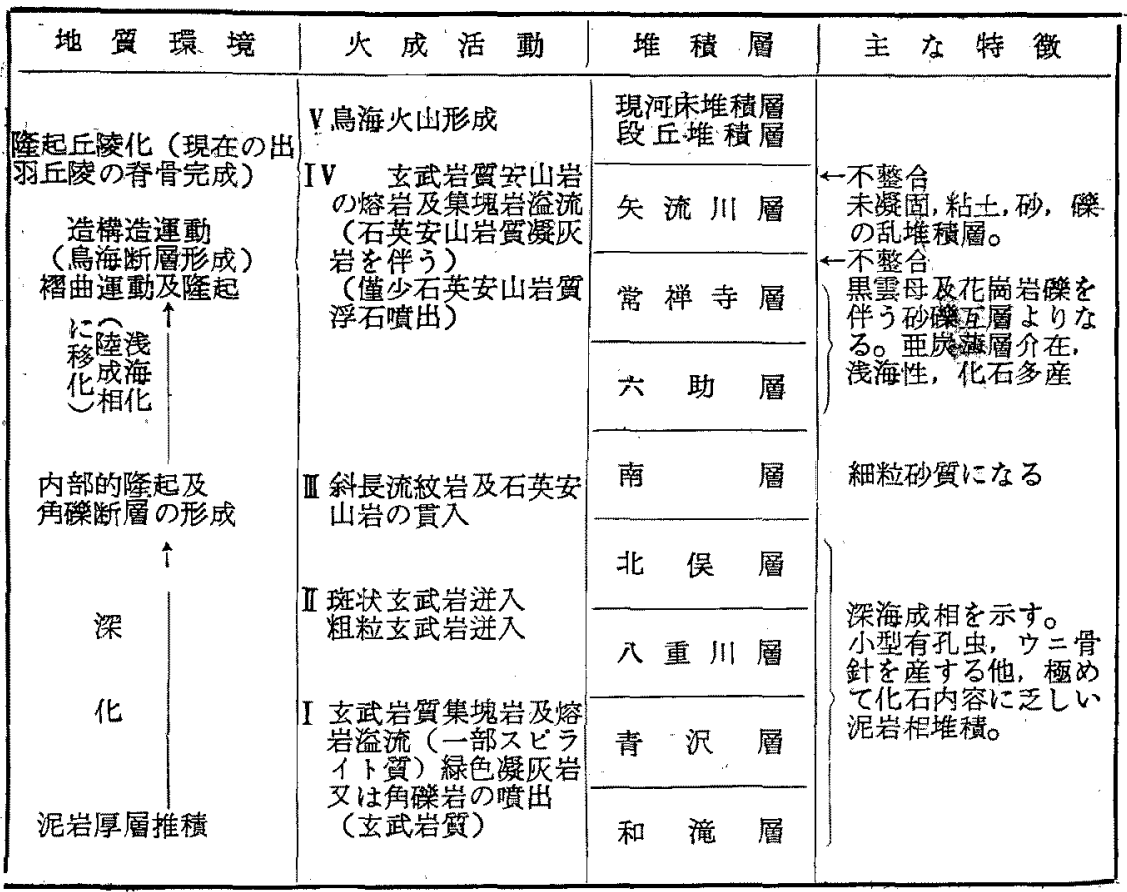

1) 第 1 期火成活動 (basic rock eruption) 主として青沢層に゙るれ る玄武岩質集塊岩及び熔岩の溢流である。又屚々同質の㠜质住磉岩に依つ て示される爆発櫴出物層をも伴う。いづれも深海成堆積の深化に伴う非常 に化石に乏しい，細粒泥岩相に依つて示される地質環境の下で著しい海底 火山作用の結果を示すものである。

岩石学的にスピライト質玄武岩のある点は，地问䣄初期火成活動として 特に注目される。

2) 第 2 期火成活動 (basic rock intrusion) 第 1 期火成活動後, 海成 梁化の末期に於计る粗粒玄武岩逰入岩体として捉えられる。白向川流域の みならず新庄盆地周辺に於いて所謂台島層中の泥岩中の粗粒玄武岩迸入岩

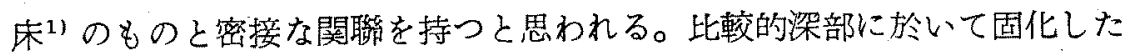
為，一般に著しい粗粒質の岩質を示す。一般に称榜石を久き，普通輝石は

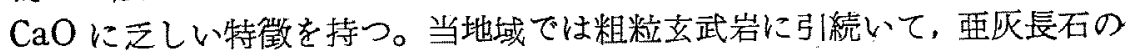
大晶を伴う斑状質玄武岩”の迸入が行われている。

1) 今田正；新庄盈地のト゚レライト群に就いて，岩磄，35，11〜15, 昭26

2) 詳細は現在㭲討中である。 
3) 第 3 期火成活動 1! (acidic rock intrusion) 南層迄堆積した海は漸

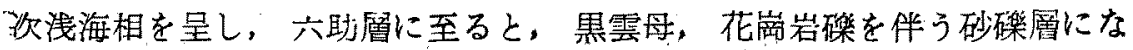
る。部分的には重宸層を介在する地層内容を示す様になる。漸次堆積盆地 恃内部的隆起の傾向を示して来る。その隆起带は現在の出羽丘陵の方向に 一致し，南方延長では，南層と六助層は不整合関係を示すに至る。六眇層 堆積に先駆した内部的隆起に前後して，造構造運動が断層争磞带として青 测層及び入重川層中に認められる。此の内部的隆起と造構造運動に相伴い 蜍長流较岩 2) の迸入が捉えられる。

4) 第 4 期火成活動 (basic rock eruption) 六助曆常融寺層堆積後, 著しい裮曲連動が認められる。此の褶曲運動に伴い，当地域の集油椲造が 形成されたと解される。褶曲運動後，出羽丘陵は隆起浮き上り，海は現在 の出羽丘陵の緣辺部に狭められ，不整合関係を以つて，矢流川喝が乱堆積 している。此の最後の堆積状態の海岸沿いに噴出したのが, 第 4 期立武岩 質安山岩類の熔岩及び集塊岩である。

5) 第 5 期火成活動（young volcanisn) 北青沢部落及び大声沢中流に

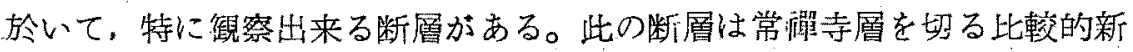
しいもので，出羽丘陵中核带の緗辺部 ${ }^{31}$ に沿い発生したものと解され る。従つて新期火山は，中核带の浮き上りに伴う断層の発生する弱線に沿 い，最後の隆起山化の完成された時期の火成活動として捉えられるもので ある。ヨーロツパの古い時代に就いての造山論に従えば final basic volcanism とされる。鳥海火山岩は橄筧石を含む比較的基性な岩質を示す点 は，此の地質䦛係の汉映とも考えられる。

\section{7 結 び}

造山論の打法に基づいての東北董日本油田地带の新生代火成活動の追求 を代表的好露出地域の当地に試み，その地質環境の解析と代表的岩石の記 載を行つたに過ざない。今後の問題としては,

1. 第 1 期火成活動以前に如何なる火成作用が行われたか。

2. 同地域に全くそしい，中性の火山岩は造山論の方法で如何にして捉え られるべきか。

3. 所謂グリンタフの膨大な火山性堆積層は如何なる地質環境に伴われる 加。

1) 八重川層及び青沢層中に酸性凝灰岩が数枚発達するが量的に少い為除いたが地 域的に発達する点重要䄈する必要がある。

2）硬䓄頁岩を切るものとして，斜長流效岩が東北日本に常識的に認められる。此れ に相当する当地では南層を質くのが忍められる。

3) 緑辺部の地質環境は火山脈の問題に関聯して別に報告の予定。 
の三つが大きく取り上げられる。此の様な点の解明に依つて，初めて新生 代火成活動の内容出上り判然として来ると思はれる。

附記 化石鑑定は浅野清，小高民夫の両氏に打願いした。㕛化学分析㤬勝井義婎氏心 御検討戴いた。此処に明記してお礼申上げる。晌此の研究は文部省科学研究費 に依つて行つだ。感譀の意を表する。

\section{福岡憬田川郡川崎町下㱏崎のベグマタイト中の輝水鉛鑛上 灰重石の㢈狀及びその周逶の地䨘に就いて}

The occurrence of molybdenite and scheelite ore in the pegmatite and the geology of Shimomasaki district, Kawasaki -machi, Fukuoka Prefecture. *

\section{林田志賀雄 (Shigao Hayashida)}

Abstract: The molybdenite and scheelite ores are fcund in the form of vein or impregnation in the pegmatite body of Shimomasaki district, and these were formed in relation to the aplite injection rather than the pegmatite.

After the solidification of pegmatite magma the residual part which has been heavily charged with $M o$ and $W$ components was injected at first as aplitic rock along the boundaries between the quartz mass and the feldspar one in the pegmatite body. The molybdenite and scheelite minerals were deposited from the dilute acidic solution chiefly into the feldspar mass after the aplitic injection. Next to above ore deposition, alkali solution invaded through the almost same passage with the ore deposition, and metamorphosed the ore body through sericitization and. carbonatization.

\section{緒書}

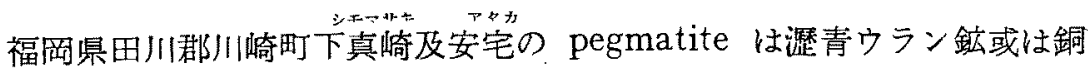
ウラン雲母その他の放射能鉱物の産地として知られている。!1213

上記両地の内，筆者は下真崎の pegmatite に付て上記の鉱物とは別 の目的で調查する機会を得た。即往時相当長期に亘つて石英を採掘した同

* 本文は第 59総会で「田川郡下真崎の pegmatite 中の蠋水鉛鉣の産状」としてそ の概略を発表したものに，更に其後の鉱床自体の精查及び周辺地域の地䁈を加えた ものである。

1) 加藤武夫：鐖床地質学

2) 木下電城：铉床学 (上巻)

3) 村上冭英：福岡景田川地区放射能鉱物産地の地筫，鉣物。九州鉱山学会誌， 